\title{
Peribronchial Proliferation of Neoplastic Cells Present
}

National Cancer Institute

\section{Source}

National Cancer Institute. Peribronchial Proliferation of Neoplastic Cells Present. NCI

Thesaurus. Code C142824.

A morphologic finding indicating the proliferation of neoplastic cells around bronchi in the lung parenchyma. 